\title{
The Content of Five Sex Steroids in Human Testis
}

\author{
L. ZAMRAZILOVÁ ${ }^{1}$, L. SOSVOROVÁ ${ }^{1}$, J. HERÁČEK ${ }^{2}$, V. SOBOTKA ${ }^{2}$, R. HAMPL $^{1}$ \\ ${ }^{1}$ Institute of Endocrinology, Prague, Czech Republic, ${ }^{2}$ Department of Urology, Third Faculty of \\ Medicine, Charles University in Prague, Czech Republic
}

Received June 29, 2011

Accepted December 9, 2011

On-line January 31, 2012

\begin{abstract}
Summary
In order to assess whether intratesticular hormone content may be helpful for prediction of successful conception in men with fertility problems, five sex steroids, testosterone, dihydrotestosterone, androstenedione, estradiol and, for the first time epitestosterone, were measured in testicular tissue obtained by surgical retrieval from total 84 men. The group consisted of non-obstructive azoospermic men, aged 21-67 years who attended the centre for in vitro fertilization. Steroids after ether extraction and solvent partition were separated by high performance liquid chromatography and then measured by specific radioimmunoassays. The values varied considerably with means \pm S.D. $2.43 \pm 2.47, \quad 0.27 \pm 0.24,0.080 \pm 0.13, \quad 0.071 \pm$ 0.089 and $0.31 \pm 0.27$ for testosterone, dihydrotestosterone, androstenedione, estradiol and epitestosterone, respectively.
\end{abstract}

\section{Key words}

Androgens $\bullet$ Estradiol $\bullet$ Epitestosterone $\bullet$ Human testis • Biopsy

\section{Corresponding author}

R. Hampl, Institute of Endocrinology, Národní 8, 11694 Prague, Czech Republic. E-mail: rhampl@endo.cz

\section{Introduction}

From the point of view of regulation, the testis represents to some extent an autonomous system characterized by an own transport mechanisms and feedback loops. It is a site of formation of endocrine/ paracrine/autocrine acting molecules as growth factors, cytokines and last but not least steroids. Among their endocrine effects, steroids mediate inter-cell communications via their intratesticular receptors.
Estradiol, for instance, besides its direct inhibitory action on testicular steroidogenesis, conducts paracrine action between Leydig and Sertoli cells (Levalle et al. 1994). Though also glucocorticoids may regulate testicular steroidogenesis by inhibiton of LH receptors expression through their own receptors in Leydig cells (Bambino and Hsueh 1981), sex steroids play the principal role in the testis. The importance of intratesticular between-cell communication is demonstrated among others by androgen-binding protein (ABP) mediating androgen transport from the site of their biosynthesis to target cells (Selva and Hammond 2006)

In spite of undoubted importance of steroids in the testis, there are not many reports on their intratesticular content. The first attempts of sex steroids determination in the human testicular tissue are dated from the seventies, for references see e.g. (Takahashi et al. 1982). They concerned young men with varicocele (McCoven et al. 1979), patients with prostate cancer (Leinonen 1980, Suescun et al. 1981, Kuber et al. 1991), various groups of infertile men with emphasis on the gonadotropin regulation of intratesticular sex steroid content (Takahashi et al. 1982, Levalle et al. 1994, Marie et al. 2001, Carreau et al. 2004), healthy male volunteers (Jarow and Zirkin 2005, Roth et al. 2010) and also post mortem tissues (Vermeulen and Deslypere 1986, Marie et al. 2001). The methods used for steroid determination differed in sample processing and not all included sufficient purification of the testicular extract. Meanwhile the methodology advanced enabling determination of minute amounts of steroids in various matrices including tissues. Here we present the data of four major sex steroids content in the whole human testicular tissue 
obtained by surgical retrieval, namely testosterone, its precursor androstenedione, dihydrotestosterone and estradiol, after their separation by high performance liquid chromatography HPLC), in view to assess whether intratesticular hormone content may be helpful for prediction of successful conception in men with fertility problems. In addition, for the first time, epitestosterone concentration was determined, believed to act as an endogenous antiandrogen (Stárka 2003).

\section{Materials and Methods}

The whole testicular tissue was obtained from 84 non-obstructive azoospermic men aged 21-67 years (mean \pm S.E.M.: $35.4 \pm 9.9$ ) by surgical retrieval. Patients were evaluated by comprehensive history, physical examination, measurement of testicular size, at least two semen analysis and hormone parameters. The latter included serum follicle stimulating hormone (mean \pm S.E.M.: 11.61 $\pm 17.55 \mathrm{U} / 1$ ), luteinizing hormone (mean \pm S.E.M.: $6.01 \pm 5.06 \mathrm{U} / \mathrm{l}$ ), prolactin (mean \pm S.E.M.: $12.05 \pm 7.08 \mu \mathrm{g} / \mathrm{l}$ ) and total testosterone (mean \pm S.E.M.: $12.63 \pm 5.61 \mathrm{nmol} / \mathrm{l})$ levels. All patients underwent screening for cystic fibrosis, Y chromosome microdeletion and karyotype analysis. Patients underwent microsurgical testicular sperm extraction (M-TESE) using optical x20-25 magnification (microscope OPMI Pico/S100, Carl Zeiss). In each case the informed written consent was obtained from the patients for working up the rests of tissues for scientific purposes. The material was immediately frozen in dry carbon dioxide and stored frozen at $-70{ }^{\circ} \mathrm{C}$ until processed. The amounts of tissue varied from 2 to $65 \mathrm{mg}$. The tissues after thawing were homogenized in $1 \mathrm{ml}$ of physiological solution, at first 1 min under increasing rate from 8000 up to $24000 \mathrm{rpm}$, and the additional $1 \mathrm{~min}$ at $24000 \mathrm{rpm}$ using Ultraturrax T25 homogenizer. The homogenate was then extracted twice with $2 \mathrm{ml}$ of diethyl ether, the ether extracts were combined and evaporated to dryness. The dry residues were partitioned between $\mathrm{n}$-hexane $(1 \mathrm{ml})$, methanol $(2 \mathrm{ml})$ and water $(0.5 \mathrm{ml})$. The upper hexane-methanolic phase containing the excessive fat was sucked off and the lower phase containing the steroids was evaporated again in the vacuum rotation evaporator. The dry residues were dissolved in $15 \%$ acetonitrile $(50 \mu \mathrm{l}, \mathrm{v} / \mathrm{v})$ and mixed properly to rinse the tube walls. The samples were centrifuged (2000 g, $3 \mathrm{~min}, 22^{\circ} \mathrm{C}$ ) and decanted solutions were transferred into chromatographic vials.

All the chemicals (analytical grade) and solvents
(HPLC grade) were purchased from Merck (Darmstadt, Germany).

HPLC was used for separation of androstenedione (AD), testosterone (T), dihydrotestosterone (DHT), epitestosterone (ET) and estradiol (E2). The system (Dionex Softron, Germering, Germany) consisted of a HPLC pump P680 equipped with automatic flow rate control, an automated sample injector ASI-100, a thermostatic column compartment TCC-100, a photodiode array detector PDA-100 with wavelength range 190-600 $\mathrm{nm}$ and a fraction collector Foxy Jr. (Teledyne ISCO, Lincoln, NE). The separation was carried out on reverse phase EC 250/4 NUCLEOSIL $® 100-5$ C18 column $(250 \times 4 \mathrm{~mm})$ with particle size of $5 \mu \mathrm{m}$ (MACHEREY-NAGEL, Düren, Germany). To avoid possible column contamination the Phenomenex SecurityGuard system with cartridge C18 $(4.0 \times 3.0 \mathrm{~mm})$ (Phenomenex, Torrance, CA) was used. For hormone separation the following protocol was used: The temperature in the column was maintained at $42{ }^{\circ} \mathrm{C}$ and the flow rate of the mobile phase was kept constant at $0.7 \mathrm{ml} / \mathrm{min}$. The following gradient profile was used: 0.0-1.5 min constant mobile phase acetonitrile-water (10:90), 1.5-17.0 min linear gradient from methanolacetonitrile-water $(57: 4.8: 38.2)$ to methanol-acetonitrilewater (68: 4.8: 27.2), 17.0-21.0 min constant mobile phase acetonitrile-water (10:90). The column was equilibrated prior to sample injection. The standard solutions of AD, T, DHT, ET and E2 were used to set up the collecting windows. AD, T and ET were detected at $244 \mathrm{~nm}$, DHT and E2 at $206 \mathrm{~nm}$. The retention times of authentic AD, DHT, T, EpiT and E2 were 14.98, 15.45, 16.47, 17.77 and $15.38 \mathrm{~min}$, respectively. The collected fractions were evaporated at $55^{\circ} \mathrm{C}$ as above and the dry residues were analyzed by radioimmunoassay using the methods developed previously in the author's laboratory,

Table 1. Intratesticular levels of five sex steroids from 84 azoospermic men, in $\mathrm{nmol} / \mathrm{g}$ tissue.

\begin{tabular}{lccccc}
\hline Steroid & Mean & S.D. & Median & $\begin{array}{c}\text { Lower } \\
\text { quartile }\end{array}$ & $\begin{array}{c}\text { Upper } \\
\text { quartile }\end{array}$ \\
\hline$T$ & 2.43 & 2.47 & 1.52 & 0.80 & 3.20 \\
$D H T$ & 0.274 & 0.244 & 0.204 & 0.104 & 0.337 \\
$A D$ & 0.080 & 0.128 & 0.043 & 0.017 & 0.106 \\
$E 2$ & 0.071 & 0.089 & 0036 & 0.015 & 0.096 \\
$E T$ & 0.309 & 0.274 & 0223 & 0.114 & 0.390 \\
\hline
\end{tabular}




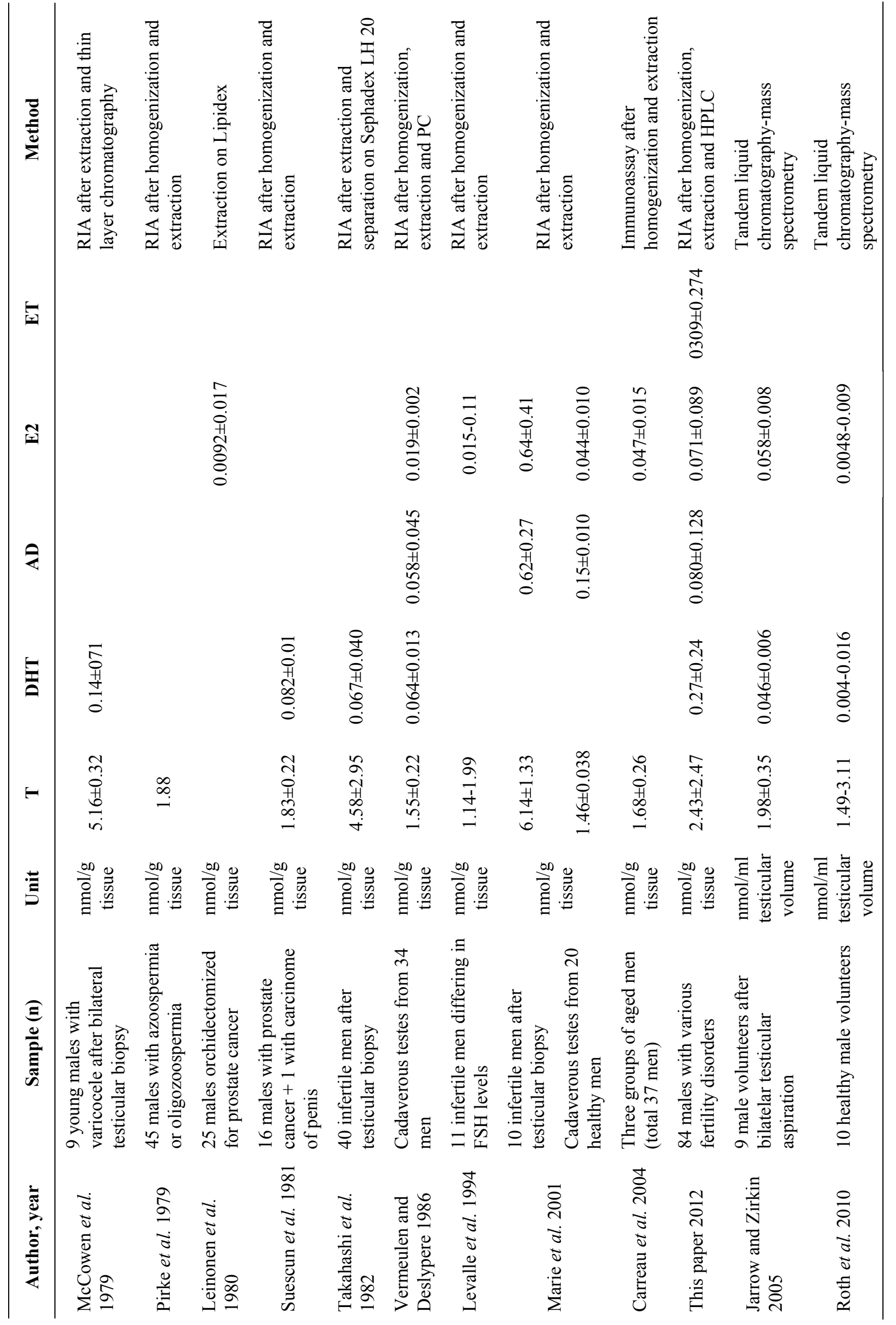


or by using commercial kits as follows: AD according to Putz et al. (1982), DHT by Hampl et al. (1990) and ET by Bílek et al. (1987). The corresponding intra-assay and inter-assay coefficients of variation (CV) in per cents were 5.8 and $11.6(\mathrm{AD}), 7.4$ and 9.6 (ET), and 8.7 and 12.1 (DHT). Testosterone was measured by commercial RIA kit from Immunotech (Czech Republic division of Beckman Coulter, Marseille, France), estradiol by radioimmunoassay kit Spectria Estradiol RIA (Orion Diagnostica Oy, Espoo, Finland). The respective intraand inter-assay CVs were 2.9 to $9.7 \%$ (T) and 2.3 to $10.2 \%$ (E2).

The losses during sample processing (extraction, solvent partition, HPLC) were estimated by spiking the pooled rests of testicular tissues (40 mg/sample) with radioactive tracers $(50000 \mathrm{dpm} / \mathrm{sample})$ and by measuring the remaining radioactivity by liquid scintillation spectrometry (Beckman LS 6000 Liquid scintillation spectrometer). The radioactive tracers $\left[1,2,6,7-{ }^{3} \mathrm{H}\right] \quad$ Testosterone, $\left[1,2,6,7-{ }^{3} \mathrm{H}\right] \quad$ Estradiol, $\left[1,2,6,7-{ }^{3} \mathrm{H}\right] \quad$ Androstenedione and $\left[1,2,4,5,6,7-{ }^{3} \mathrm{H}\right]$ Dihydrotestosterone were purchased from Perkin Elmer Life and Analytical Sciences (Boston, MA, USA). The recovery of tracers varied from 36.7 to 45.6 with mean $41.1 \%$. The results including those for ET were corrected for this value.

\section{Results}

The results of determination of five sex steroids in samples of testicular tissues from eighty four non- obstructive azoospermic men are shown in Table 1. The means, standard deviations, medians and upper and lower quartiles are provided. In the Table 2 the data are compared with those reported by other authors.

\section{Discussion}

The concentrations of testosterone are lower than those reported by early studies which did not use chromatographic separation of the ether extract but agree well with more recent ones. The values of estradiol and androstenedione are comparable with previous findings (Takahashi et al. 1982, Levalle et al. 1994). We have found higher intratesticular concentrations of dihydrotestosterone but the groups of subjects in other reports were much smaller. For the first time the values are provided for all steroids of interest in one sample, namely testosterone, its precursor androstenedione and 5alpha-reduced metabolite dihydrotestosterone, together with estradiol and epitestosterone. The number of samples and their heterogeneity do not allow statistical evaluation of the relation to the patient's state, especially the sperm parameters, but the method is satisfactory for use in a larger number of samples.

\section{Conflict of Interest}

There is no conflict of interest.

\section{Acknowledgements}

The study was supported by the Internal Grant Agency of the Ministry of Health, grant No. NS-9967-4.

\section{References}

BAMBINO TH, HSUEH AJ: Direct inhibitory effect of glucocorticoids upon testicular luteinizing hormone receptor and steroidogenesis in vivo and in vitro. Endocrinology 108: 2142-2148, 1981.

BÍLEK R, HAMPL R, PUTZ Z, STÁRKA L: Radioimmunoassay of epitestosterone: methodology, thermodynamic aspects and applications. $J$ Steroid Biochem 28: 723-729, 1987.

CARREAU S, BOURGUIBA S, MARIE E: Testicular and blood steroid levels in aged men. Reprod Biol 4: 299-304, 2004.

HAMPL R, PUTZ Z, STÁRKA L: Radioimmunological determination of dihydrotestosterone and its importance for laboratory diagnostics (in Czech). Biochem Clin Bohemoslov 19: 157-163, 1990.

JAROW JP, ZIRKIN BR: The androgen microenvironment of the human testis and hormonal control of spermatogenesis. Ann N Y Acad Sci 1061: 208-220, 2005.

KUBER W, VIEHBERGER G, ZEILLINGER R, SPONA J: Effects of the duration of therapy with the LHRH agonist D-ser (BUT)6 Azgly10-LHRH (ICI 118-630) on the steroid hormone content and the morphology of human testicular tissue in the treatment of patients with advanced prostate cancer. Urol Res 19: 19-24, 1991.

LEINONEN P: Estrone and estradiol concentrations in the testis and spermatic and peripheral venous blood of elderly men: the influence of estrogen treatment. J Steroid Biochem 13: 737-742, 1980. 
LEVALLE OA, ZYLBERSZTEIN C, ASZPIS S, MARIANI V, PONZIO R, ARANDA C, GUITELMAN A, SCAGLIA HE: Serum luteinizing hormone pulsatility and intratesticular testosterone and oestradiol concentrations in idiopathic infertile men with high and normal follicle stimulating hormone serum concentrations. Hum Reprod 9: 781-787, 1994.

MARIE E, GALERAUD-DENIS I, CARREAU S: Increased testicular steroid concentrations in patients with idiopathic infertility and normal FSH levels. Arch Androl 47: 177-184, 2001.

MCCOWEN KD, SMITH ML, MODARELLI RO, FARISS BL, REED JW: Tissue testosterone and dihydrotestosterone from bilateral testis biopsies in males with varicocele. Fertil Steril 32: 439-442, 1979.

PIRKE KM, VOGT HJ, LEHNIG W, SINTERMANN R: Intratesticular testosterone concentration in patients with disturbed fertility. Andrologia 11: 320-325, 1979.

PUTZ Z, HAMPL R, VAŇUGA A, VELEMÍNSKÝ J, STÁRKA L: A selective radioimmunoassay of androstenedione in plasma and saliva. J Clin Chem Clin Biochem 20: 761-764, 1982.

ROTH MY, LIN K, AMORY JK, MATSUMOTO AM, ANAWALT BD, SNYDER CN, KALHORN TF, BREMNER WJ, PAGE ST: Serum LH correlates highly with intratesticular steroid levels in normal men. J Androl 31: 138$145,2010$.

SCHLEGEL PN: Testicular sperm extraction: microdissection improves sperm yield with minimal tissue excision. Hum Reprod 14: 131-135, 1999.

SELVA DM, HAMMOND G: Human sex hormone-binding globulin is expressed in testicular germ cells and not in sertoli cells. Horm Metab Res 14: 230-235, 2006.

STÁRKA L: Epitestosterone. J Steroid Biochem Mol Biol 87: 27-34, 2003.

SUESCUN MO, CAMPO S, RIVAROLA MA, GONZÁLEZ-ECHEVERRÍA F, SCORTICATI C, GHIRLANDA J, TEZÓN J, BLAQUIER JA, CALANDRA RS: Testosterone, dihydrotestosterone, and zinc concentrations in human testis and epididymis. Arch Androl 7: 297-303, 1981.

TAKAHASHI J, HIGASHI Y, LANASA JA, WINTERS SJ, OSHIMA H, TROEN P: Studies of the human testis. XVII. Gonadotropin regulation of intratesticular testosterone and estradiol in infertile men. J Clin Endocrinol Metab 55: 1073-1080, 1982.

VERMEULEN A, DESLYPERE JP: Intratesticular unconjugated steroids in elderly men. J Steroid Biochem 24: 10791083, 1986. 